\title{
Pseudomonas bauzanensis sp. nov., isolated from soil
}

\author{
De-Chao Zhang, ${ }^{1}$ Hong-Can Liu, ${ }^{2}$ Yu-Guang Zhou, ${ }^{2}$ Franz Schinner ${ }^{1}$ \\ and Rosa Margesin ${ }^{1}$
}

Correspondence

Rosa Margesin

Rosa.Margesin@uibk.ac.at

\author{
${ }^{1}$ Institute of Microbiology, University of Innsbruck, Technikerstrasse 25, A-6020 Innsbruck, Austria \\ ${ }^{2}$ China General Microbiological Culture Collection Center and State Key Laboratory of Microbial \\ Resources, Institute of Microbiology, Chinese Academy of Sciences, Beijing 100101, PR China
}

The genus Pseudomonas was originally created by Migula (1894). Bacteria of the genus Pseudomonas belong to the Gammaproteobacteria and are aerobic, chemoorganotrophic, non-spore-forming, motile, Gram-negative rods with polar flagella and a respiratory rather than a fermentative metabolism (Palleroni, 1984; Timmis, 2002). Over the years, species of the genus have been reclassified and revised several times (Sneath et al., 1981; Oyaizu \& Komagata, 1983; Vancanneyt et al., 1996; Anzai et al., 2000). Members of the genus Pseudomonas are widely distributed in soil, water, air, plants and many other natural habitats (Palleroni, 1992). Some representatives of this genus colonize cold habitats (Yumoto et al., 2001; Reddy et al., 2004; Bozal et al., 2007; Margesin et al., 2008). The present study deals with the characterization of a novel strain of the genus Pseudomonas that was isolated from soil and is able to grow at low temperatures.

Strain $\mathrm{BZ}^{\mathrm{T}}{ }^{\mathrm{T}}$ was isolated from soil from an industrial site (containing high amounts of heavy oil and heavy metals) in Bozen, South Tyrol, Italy, as described previously (Zhang et al., 2010). The soil was sampled and processed under sterile conditions in spring 2008. A sample (10 g) was shaken with $90 \mathrm{ml}$ sterile $1 \%$ sodium pyrophosphate for $20 \mathrm{~min}$ at

The GenBank/EMBL/DDBJ accession number for the $16 \mathrm{~S}$ rRNA gene sequence of strain BZ93 ${ }^{\top}$ is GQ161991.

A supplementary table and a supplementary figure are available with the online version of this paper.
150 r.p.m. Appropriate dilutions were prepared with sterile $0.9 \% \mathrm{NaCl}$ and $0.1 \mathrm{ml}$ aliquots were spread on $\mathrm{R}_{2} \mathrm{~A}$ agar $(0.05 \%$ yeast extract, $0.05 \%$ peptone, $0.05 \%$ Casamino acids, $0.05 \%$ glucose, $0.05 \%$ starch, $0.03 \%$ sodium pyruvate, $0.03 \% \mathrm{~K}_{2} \mathrm{HPO}_{4}, 0.005 \% \mathrm{MgSO}_{4}, 1.5 \%$ agar; $\mathrm{pH} 7$; Reasoner \& Geldreich, 1985) and incubated at $20{ }^{\circ} \mathrm{C}$. A white colony was purified and designated $\mathrm{BZ} 93^{\mathrm{T}}$. Strain $\mathrm{BZ} 93^{\mathrm{T}}$ was routinely cultured on $\mathrm{R}_{2} \mathrm{~A}$ medium at $20{ }^{\circ} \mathrm{C}$ and maintained as a suspension in skimmed milk $(10 \% \mathrm{w} / \mathrm{v})$ at $-80{ }^{\circ} \mathrm{C}$. Pseudomonas pertucinogena LMG $1874^{\mathrm{T}}$ and Pseudomonas xiamenensis CGMCC $1.6446^{\mathrm{T}}$ were routinely grown on $\mathrm{R}_{2} \mathrm{~A}$ agar at $25{ }^{\circ} \mathrm{C}$ and used as reference strains.

DNA was extracted and purified as described by Sambrook et al. (1989). The 16S rRNA gene was amplified by PCR using universal primers (27F, 5' ${ }^{\prime}$-AGAGTTTGATCCTGGCTCAG-3'; 1541R, 5' -AAGGAGGTGATCCAGCCGCA-3'). PCR products were cloned into the pGEM-T vector (Promega) according to the manufacturer's instructions. FASTA similarity searches were done using the GenBank and EMBL databases. A pairwise comparison of the 16S rRNA gene sequences was analysed using EzTaxon (Chun et al., 2007). The $16 \mathrm{~S}$ rRNA gene sequence of strain $\mathrm{BZ} 93^{\mathrm{T}}$ showed 97.8 and $97.4 \%$ similarity with $P$. xiamenensis $\mathrm{C} 10-2^{\mathrm{T}}$ and $P$. pertucinogena IFO $14163^{\mathrm{T}}$, respectively. Similarities between strain $\mathrm{BZ} 93^{\mathrm{T}}$ and other members of the genus Pseudomonas were $<96.5 \%$.

Phylogenetic analysis was performed using MEGA version 4.0 (Tamura et al., 2007) and PHYLIP version 3.69 
(Felsenstein, 2009) after multiple alignment of data using CLUSTAL x version 1.8 (Thompson et al., 1997). For neighbour-joining analysis (Saitou \& Nei, 1987), genetic distances were calculated using Kimura's two-parameter model (Kimura, 1980). Strain $\mathrm{BZ} 3^{\mathrm{T}}$ fell within the genus Pseudomonas and formed a distinct cluster with $P$. xiamenensis $\mathrm{C} 10-2^{\mathrm{T}}$ and $P$. pertucinogena IFO $14163^{\mathrm{T}}$ (Fig. 1). The relative position of strain $\mathrm{BZ}^{\mathrm{T}}{ }^{\mathrm{T}}$ was also confirmed in the maximum-likelihood tree.

Cell morphology was examined by phase-contrast microscopy $(\times 1000)$ of cells grown on $\mathrm{R}_{2} \mathrm{~A}$ agar at $20{ }^{\circ} \mathrm{C}$. Colony morphology was also observed on $\mathrm{R}_{2} \mathrm{~A}$ agar at $20{ }^{\circ} \mathrm{C}$. Motility of cells grown at $20{ }^{\circ} \mathrm{C}$ was evaluated on motility agar (API M; bioMérieux) and under a light microscope $(\times 1000)$.

All of the following tests were done with strain $\mathrm{BZ} 93^{\mathrm{T}}$ and the reference strains. The Gram reaction was tested by Gram staining and confirmed by the $\mathrm{KOH}$-lysis test.
Pigment analysis was performed as described by Hildebrand et al. (1994). To test for the production of a cellular (methanol-extractable) pigment, cells were grown for 4 days at $25{ }^{\circ} \mathrm{C}$ on King's $\mathrm{B}$ agar and nutrient agar. To test for the presence of a diffusible pigment, cells were grown for $48 \mathrm{~h}$ at $25{ }^{\circ} \mathrm{C}$ and 200 r.p.m. in King's B broth and nutrient broth. Catalase activity was determined by bubble production in $3 \%(\mathrm{v} / \mathrm{v}) \mathrm{H}_{2} \mathrm{O}_{2}$. Oxidase activity was determined using $1 \%(\mathrm{w} / \mathrm{v}) \quad N, N, N^{\prime}, N^{\prime}$-tetramethyl- $p$ phenylenediamine. The API $20 \mathrm{E}$, API $20 \mathrm{NE}$ and API ZYM systems (bioMérieux) and EcoPlates (Biolog) were used at $25{ }^{\circ} \mathrm{C}$ to determine physiological and biochemical characteristics and enzyme activities. $\beta$-Galactosidase, amylase and lipase esterase activities were additionally tested using $\mathrm{R}_{2} \mathrm{~A}$ agar supplemented with appropriate substrates (Margesin et al., 2003). Growth at $1-45{ }^{\circ} \mathrm{C}$ was assessed on $\mathrm{R}_{2} \mathrm{~A}$ agar and in $\mathrm{R}_{2} \mathrm{~A}$ liquid medium at 150 r.p.m. Growth at pH 5-9 and with $0-20 \%(w / v) ~ N a C l$ was determined on $\mathrm{R}_{2} \mathrm{~A}$ agar at $20^{\circ} \mathrm{C}$. Susceptibility to antibiotics was determined at $25{ }^{\circ} \mathrm{C}$ using antibiotic

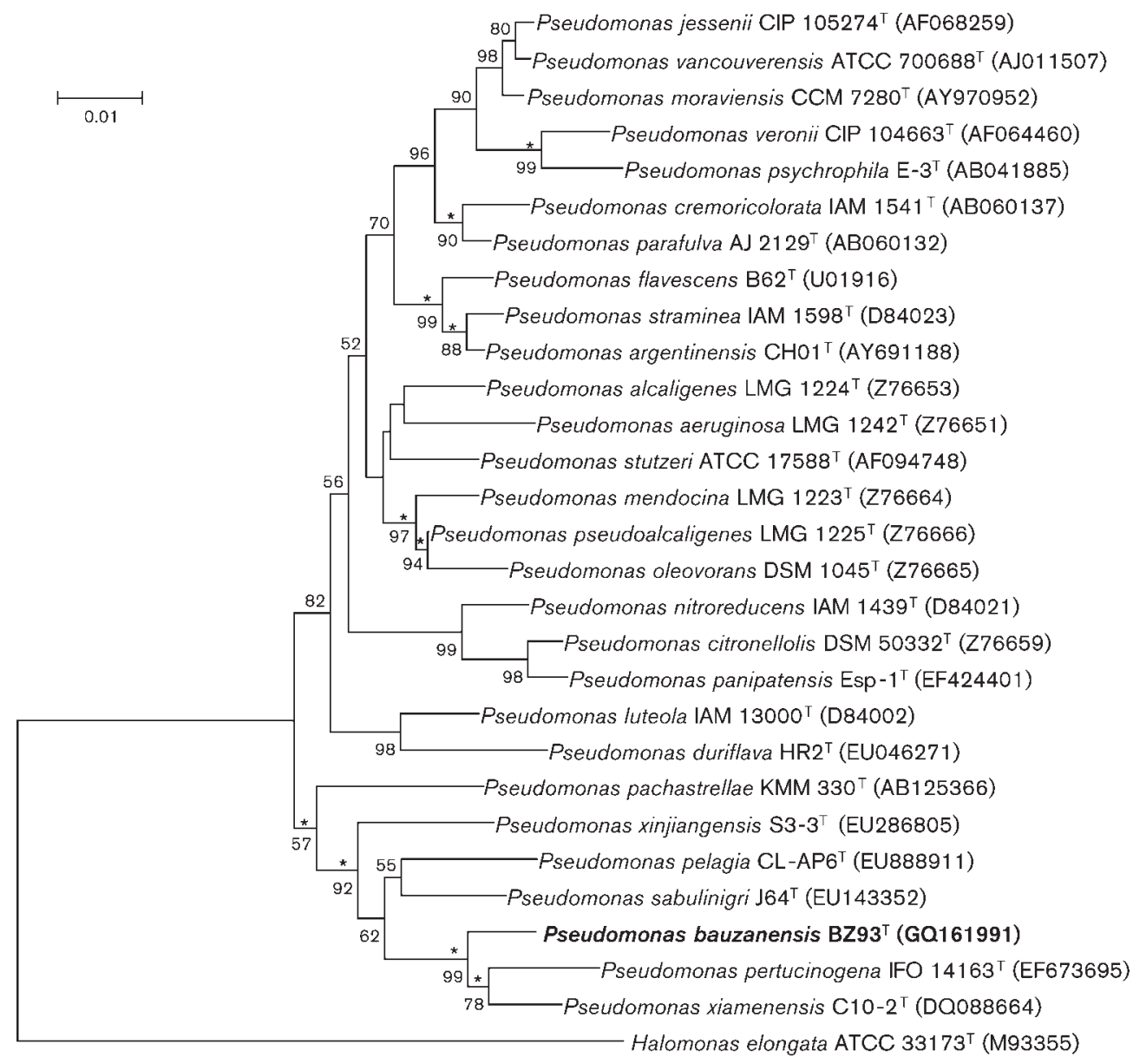

Fig. 1. Neighbour-joining tree based on 16S rRNA gene sequences, showing the phylogenetic position of strain $B Z 93^{\top}$ within the genus Pseudomonas. Bootstrap values (>50\%) based on 1000 resamplings are shown at branch nodes. Asterisks indicate that the corresponding nodes were also recovered in the maximum-likelihood tree. Halomonas elongata ATCC $33173^{\top}$ was used as an outgroup. Bar, 0.01 nucleotide substitutions per site. 
discs (bioMérieux). The morphological, physiological and biochemical characteristics of strain $\mathrm{BZ}^{\mathrm{T}}{ }^{\mathrm{T}}$ are given in the species description and Table 1 . The features that serve to differentiate strain $\mathrm{BZ} 93^{\mathrm{T}}$ from $P$. xiamenensis CGMCC $1.6446^{\mathrm{T}}$ and $P$. pertucinogena LMG $1874^{\mathrm{T}}$ are given in Table 1.

Respiratory quinones were extracted and purified according to Collins (1985) and were analysed by HPLC (Wu

Table 1. Phenotypic characteristics that differentiate strain $\mathrm{BZ}^{\mathrm{T}}{ }^{\mathrm{T}}$ from its closest phylogenetic neighbours

Strains: 1 , Pseudomonas bauzanensis sp. nov. $\mathrm{BZ}^{\mathrm{T}} 3^{\mathrm{T}} ; 2$, P. xiamenensis CGMCC $1.6446^{\mathrm{T}} ; 3$, P. pertucinogena LMG $1874^{\mathrm{T}}$. All data were taken from this study. All strains are positive for catalase, cytochrome oxidase, esterase (C4), esterase lipase (C8), leucine arylamidase, acid phosphatase, naphthol-AS-BI-phosphohydrolase and assimilation of capric acid and malic acid. All strains are negative for $\alpha$ - and $\beta$-galactosidase, $\beta$-glucuronidase, $\alpha$ - and $\beta$-glucosidase, $N$-acetyl- $\beta$ glucosaminidase, $\alpha$-mannosidase, $\alpha$-fucosidase, arginine dihydrolase, lysine dihydrolase, ornithine dihydrolase, citrate utilization, $\mathrm{H}_{2} \mathrm{~S}$ production, urease production, tryptophan deaminase, indole production, gelatinase, aesculin hydrolysis and utilization of Larabinose, D-mannose, D-mannitol, maltose, $\mathrm{N}$-acetylglucosamine, phenylacetic acid, gluconate (API $20 \mathrm{NE}$ ), D-glucosaminic acid, Dgalacturonic acid, $\gamma$-hydroxybutyric acid, cellobiose, $\alpha$-lactose, methyl $\beta$-D-glucoside, D-xylose, i-erythritol, glucose 1-phosphate, DL- $\alpha$ glycerol phosphate, D-galacturonic acid, $\gamma$-lactone, L-arginine, $\mathrm{L}$ asparagine, L-phenylalanine, L-threonine, glycyl L-glutamic acid, phenylethylamine, putrescine, 2-hydroxybenzoic acid, 4-hydroxybenzoic acid, $\alpha$-cyclodextrin and glycogen (EcoPlates). + , Positive; $w$, weakly positive; -, negative.

\begin{tabular}{|c|c|c|c|}
\hline Characteristic & 1 & 2 & 3 \\
\hline \multicolumn{4}{|l|}{ Growth at/with: } \\
\hline $5{ }^{\circ} \mathrm{C}$ & + & - & - \\
\hline $10{ }^{\circ} \mathrm{C}$ & + & + & - \\
\hline $37^{\circ} \mathrm{C}$ & - & - & + \\
\hline $\mathrm{pH} 9$ & - & + & - \\
\hline $7 \%(w / v) \mathrm{NaCl}$ & + & + & - \\
\hline $10 \%(w / v) \mathrm{NaCl}$ & + & - & - \\
\hline Nitrate reduction & - & + & - \\
\hline \multicolumn{4}{|l|}{ Enzyme activities (API ZYM) } \\
\hline Cystine arylamidase & - & - & + \\
\hline Trypsin & - & - & + \\
\hline$\alpha$-Chymotrypsin & - & - & + \\
\hline Glucose fermentation & - & - & + \\
\hline \multicolumn{4}{|l|}{ Utilization (API $20 \mathrm{NE}$ ) } \\
\hline Adipic acid & + & - & + \\
\hline Trisodium citrate & + & + & - \\
\hline \multicolumn{4}{|l|}{ Utilization (EcoPlates) } \\
\hline Pyruvic acid methyl ester & + & - & - \\
\hline 4-Hydroxybenzoic acid & - & - & + \\
\hline Itaconic acid & + & - & - \\
\hline$\alpha$-Ketobutyric acid & + & - & - \\
\hline L-Serine & $\mathrm{W}$ & - & - \\
\hline
\end{tabular}

et al., 1989). The quinone system consisted predominantly of ubiquinone Q-9.

For fatty acid methyl ester analysis, cell mass of strain $\mathrm{BZ}^{\mathrm{T}}{ }^{\mathrm{T}}$ and the reference strains was harvested from trypticase soy agar after incubation at $25^{\circ} \mathrm{C}$ for 3 days. The fatty acid methyl esters were extracted and prepared according to the standard protocol of the Sherlock Microbial Identification System (MIDI; Sasser, 1990). The predominant cellular fatty acids of strain $\mathrm{BZ} 93^{\mathrm{T}}$ were $\mathrm{C}_{18: 1} \omega 7 c(54.8 \%)$, summed feature $3\left(\mathrm{C}_{16: 1} \omega 7 c\right.$ and/or iso- $\left.\mathrm{C}_{15: 0} 2-\mathrm{OH} ; 10.3 \%\right), \mathrm{C}_{16: 0}(9.9 \%)$ and $\mathrm{C}_{17: 0}$ cyclo $(7.4 \%)$. The fatty acid profiles of strain $\mathrm{BZ}^{\mathrm{T}}{ }^{\mathrm{T}}, P$. xiamenensis CGMCC1.6446 ${ }^{\mathrm{T}}$ and $P$. pertucinogena LMG $1874^{\mathrm{T}}$ are shown in Supplementary Table S1 (available in IJSEM Online).

The cellular polar lipids were extracted and analysed on silica gel plates (Kieselgel 60 F; Merck) by TLC (Kates, 1986) and staining with molybdatophosphoric acid. The polar lipid profile of strain $\mathrm{BZ}^{\mathrm{T}}{ }^{\mathrm{T}}$ consisted of phosphatidylethanolamine, diphosphatidylglycerol, phosphatidylglycerol and an unknown phospholipid. An unknown aminophospholipid and 11 unknown polar lipids were also detected (Supplementary Fig. S1, available in IJSEM Online).

The $\mathrm{G}+\mathrm{C}$ content was determined by the thermal denaturation method (Marmur \& Doty, 1962) with Escherichia coli $\mathrm{K}-12$ as the reference strain, and DNA-DNA hybridization was done by the liquid renaturation method (De Ley et al., 1970) as modified by Huß et al. (1983). Both experiments were carried out using a model Lambda 35 UV/VIS spectrometer equipped with a temperature program controller (Perkin-Elmer). The DNA G+C content of strain $\mathrm{BZ}^{\mathrm{T}}{ }^{\mathrm{T}}$ was $61.8 \mathrm{~mol} \%$. DNA-DNA relatedness between strain $\mathrm{BZ}^{\mathrm{T}}$ and $P$. xiamenensis CGMCC $1.6446^{\mathrm{T}}$ and $P$. pertucinogena LMG $1874^{\mathrm{T}}$ was 32.5 and $26.6 \%$, respectively.

The results presented above demonstrate that strain $B Z 93^{\mathrm{T}}$ is a member of the genus Pseudomonas. Strain BZ93 ${ }^{\mathrm{T}}$ could be easily differentiated from its closest phylogenetic neighbours by its ability to grow well at $5{ }^{\circ} \mathrm{C}$ and with $10 \%(\mathrm{w} / \mathrm{v}) \mathrm{NaCl}$ and to utilize a number of carboxylic acids (pyruvic acid methyl ester, itaconic acid and $\alpha$ ketobutyric acid). In addition, strain $\mathrm{BZ}^{\mathrm{T}} 3^{\mathrm{T}}$ could be differentiated from $P$. xiamenensis CGMCC $1.6446^{\mathrm{T}}$ by its inability to reduce nitrate and to grow at $\mathrm{pH} 9$ and its ability to assimilate adipic acid, as well as by having higher amounts of the cellular fatty acid $\mathrm{C}_{18: 1} \omega 7 c$ and smaller amounts of $\mathrm{C}_{19: 0}$ cyclo $\omega 8 c$. Strain $\mathrm{BZ}^{\mathrm{T}}$ could be differentiated from $P$. pertucinogena LMG $1874^{\mathrm{T}}$ by its inability to grow at $37^{\circ} \mathrm{C}$, ferment glucose and utilize 4-hydroxybenzoic acid, by the absence of cystine arylamidase, trypsin and $\alpha$-chymotrypsin and its ability to assimilate trisodium citrate and grow with $7 \%(\mathrm{w} / \mathrm{v})$ $\mathrm{NaCl}$ and at $10{ }^{\circ} \mathrm{C}$, as well as by having higher amounts of the cellular fatty acids $\mathrm{C}_{18: 1} \omega 7 c, \mathrm{C}_{17: 0}$ cyclo and $\mathrm{C}_{19: 0}$ cyclo $\omega 8 \mathrm{c}$ and smaller amounts of summed feature 3. 
Therefore, on the basis of phenotypic, phylogenetic and genomic evidence, strain $\mathrm{BZ} 93^{\mathrm{T}}$ was identified as a representative of a novel species of the genus Pseudomonas, for which the name Pseudomonas bauzanensis sp. nov. is proposed.

\section{Description of Pseudomonas bauzanensis sp. nov.}

Pseudomonas bauzanensis (bau.za.nen'sis. N.L. fem. adj. bauzanensis referring to Bauzanum medieval Latin name of Bozen/Bolzano, a city in South Tyrol, Italy, where the species was first isolated).

Cells are aerobic, Gram-negative, motile, short rods (0.7$0.9 \times 1.1-1.7 \mu \mathrm{m}$ after 4 days at $20{ }^{\circ} \mathrm{C}$ on $\mathrm{R}_{2} \mathrm{~A}$ agar). Grows on $\mathrm{R}_{2} \mathrm{~A}$ agar, nutrient agar, trypticase soy agar and King's $\mathrm{B}$ agar. Colonies on $\mathrm{R}_{2} \mathrm{~A}$ agar are white, round, convex, smooth and with entire margins $(1.5-2 \mathrm{~mm}$ in diameter after 6 days at $20{ }^{\circ} \mathrm{C}$ ). Negative for production of a cellular (methanol-extractable) or diffusible fluorescent pigment. Good growth occurs in $\mathrm{R}_{2} \mathrm{~A}$ liquid medium at $5-30{ }^{\circ} \mathrm{C}$ (highest cell yields at $10-20{ }^{\circ} \mathrm{C}$ ); growth at 1 and $37^{\circ} \mathrm{C}$ is absent in $\mathrm{R}_{2} \mathrm{~A}$ liquid culture and on $\mathrm{R}_{2} \mathrm{~A}$ agar plates. On $\mathrm{R}_{2} \mathrm{~A}$ agar, growth occurs at $\mathrm{pH} 7-8$ and with $0-7 \%(\mathrm{w} / \mathrm{v}) \mathrm{NaCl}$; growth is delayed with $10 \%(\mathrm{w} / \mathrm{v}) \mathrm{NaCl}$ and absent with $15 \%(\mathrm{w} / \mathrm{v}) \mathrm{NaCl}$. Produces catalase and cytochrome oxidase. Negative for production of indole, $\mathrm{H}_{2} \mathrm{~S}$ and urease, utilization of citrate, reduction of nitrate and hydrolysis of aesculin. Positive for acid phosphatase, alkaline phosphatase, esterase (C4), esterase lipase (C8), naphthol-AS-BIphosphohydrolase and leucine arylamidase; weakly positive for valine arylamidase and lipase (C14); and negative for gelatinase, amylase, arginine dihydrolase, lysine dihydrolase, ornithine dihydrolase, tryptophan deaminase, trypsin, $\alpha$ chymotrypsin, cystine arylamidase, $N$-acetyl- $\beta$-glucosaminidase, $\alpha$ - and $\beta$-galactosidase, $\beta$-glucuronidase, $\alpha$ - and $\beta$ glucosidase, $\alpha$-mannosidase and $\alpha$-fucosidase. With API 20 $\mathrm{NE}$, assimilates capric acid, adipic acid, malic acid and trisodium citrate, but not D-glucose, D-mannitol, maltose, Larabinose, D-mannose, $\mathrm{N}$-acetylglucosamine, gluconate or phenylacetic acid. With EcoPlates, utilizes pyruvic acid methyl ester, itaconic acid, $\alpha$-ketobutyric acid, D-malic acid, Tweens 40 and 80 and weakly utilizes L-serine, but does not utilize D-glucosaminic acid, D-galacturonic acid, $\gamma$-hydroxybutyric acid, cellobiose, $\alpha$-lactose, methyl $\beta$-D-glucoside, Dxylose, i-erythritol, D-mannitol, $N$-acetyl-D-glucosamine, glucose 1-phosphate, DL- $\alpha$-glycerol phosphate, D-galacturonic acid, $\gamma$-lactone, L-arginine, L-asparagine, L-phenylalanine, L-threonine, glycyl L-glutamic acid, phenylethylamine, putrescine, 2-hydroxybenzoic acid, 4-hydroxybenzoic acid, $\alpha$-cyclodextrin or glycogen. Does not ferment glucose, mannitol, sucrose, inositol, sorbitol, rhamnose, melibiose, amygdalin or L-arabinose. Resistant to ( $\mu \mathrm{g}$ per disc) tetracycline (30) and erythromycin (15), and sensitive to kanamycin (30), amikacin (30), gentamicin (10), streptomycin (10), ampicillin (10), nalidixic acid (30), chlorampheni$\mathrm{col}$ (30) and rifampicin (30). The predominant cellular fatty acids are $\mathrm{C}_{18: 1} \omega 7 c$, summed feature $3\left(\mathrm{C}_{16: 1} \omega 7 c\right.$ and/or iso- $\left.\mathrm{C}_{15: 0} 2-\mathrm{OH}\right), \mathrm{C}_{16: 0}$ and $\mathrm{C}_{17: 0}$ cyclo. The quinone system consists predominantly of ubiquinone Q-9. The polar lipid profile consists of phosphatidylethanolamine, diphosphatidylglycerol, phosphatidylglycerol and an unknown phospholipid; an unknown aminophospholipid and 11 unknown polar lipids are also present. The DNA G $+\mathrm{C}$ content of the type strain is $61.8 \mathrm{~mol} \%$.

The type strain is $\mathrm{BZ}^{\mathrm{T}}{ }^{\mathrm{T}}\left(=\mathrm{DSM} 22558^{\mathrm{T}}=\right.$ CGMCC $1.9095^{\mathrm{T}}$ $=\mathrm{LMG} 26048^{\mathrm{T}}$ ) and was isolated from soil contaminated with hydrocarbons and heavy metals in Bozen, South Tyrol, Italy.

\section{Acknowledgements}

This work was supported by the Autonome Provinz Bozen, Südtirol. We thank P. Thurnbichler and J. Mair for technical assistance.

\section{References}

Anzai, Y., Kim, H., Park, J.-Y., Wakabayashi, H. \& Oyaizu, H. (2000). Phylogenetic affiliation of the pseudomonads based on 16S rRNA sequence. Int J Syst Evol Microbiol 50, 1563-1589.

Bozal, N., Montes, M. J. \& Mercadé, E. (2007). Pseudomonas guineae sp. nov., a novel psychrotolerant bacterium from an Antarctic environment. Int J Syst Evol Microbiol 57, 2609-2612.

Chun, J., Lee, J.-H., Jung, Y., Kim, M., Kim, S., Kim, B. K. \& Lim, Y.-W. (2007). EzTaxon: a web-based tool for the identification of prokaryotes based on $16 \mathrm{~S}$ ribosomal RNA gene sequences. Int J Syst Evol Microbiol 57, 2259-2261.

Collins, M. D. (1985). Isoprenoid quinone analysis in classification and identification. In Chemical Methods in Bacterial Systematics, pp. 267-287. Edited by M. Goodfellow \& D. E. Minnikin. London: Academic Press.

De Ley, J., Cattoir, H. \& Reynaerts, A. (1970). The quantitative measurement of DNA hybridization from renaturation rates. Eur $J$ Biochem 12, 133-142.

Felsenstein, J. (2009). PHYLIP (phylogeny inference package) version 3.69. Distributed by the author. Department of Genome Sciences, University of Washington, Seattle, USA.

Hildebrand, D. C., Palleroni, N. J., Hendson, M., Toth, J. \& Johnson, J. L. (1994). Pseudomonas flavescens sp. nov., isolated from walnut blight cankers. Int J Syst Bacteriol 44, 410-415.

Huß, V. A. R., Festl, H. \& Schleifer, K. H. (1983). Studies on the spectrophotometric determination of DNA hybridization from renaturation rates. Syst Appl Microbiol 4, 184-192.

Kates, M. (1986). Techniques of Lipidology, 2nd edn. Amsterdam: Elsevier.

Kimura, M. (1980). A simple method for estimating evolutionary rates of base substitutions through comparative studies of nucleotide sequences. J Mol Evol 16, 111-120.

Margesin, R., Gander, S., Zacke, G., Gounot, A. M. \& Schinner, F. (2003). Hydrocarbon degradation and enzyme activities of coldadapted bacteria and yeasts. Extremophiles 7, 451-458.

Margesin, R., Schinner, F., Marx, J. C. \& Gerday, C. (editors) (2008). Psychrophiles - from Biodiversity to Biotechnology. Heidelberg: Springer.

Marmur, J. \& Doty, P. (1962). Determination of the base composition of deoxyribonucleic acid from its thermal denaturation temperature. J Mol Biol 5, 109-118. 
Migula, W. (1894). Über ein neues System der Bakterien. Arb Bakteriol Inst Karlsruhe 1, 235-238 (in German).

Oyaizu, H. \& Komagata, K. (1983). Grouping of Pseudomonas species on the basis of cellular fatty acid composition and the quinone system with special reference to the existence of 3-hydroxy fatty acids. J Gen Appl Microbiol 29, 17-40.

Palleroni, N. J. (1984). Genus I. Pseudomonas Migula 1894, $237^{\mathrm{AL}}$ (nom. cons. Opin. 5, Jud. Comm. 1952, 237). In Bergey's Manual of Systematic Bacteriology, vol. 1, pp. 141-199. Edited by N. R. Krieg \& J. G. Holt. Baltimore: Williams \& Wilkins.

Palleroni, N. J. (1992). Introduction to the family Pseudomonadaceae. In The Prokaryotes, 2nd edn, pp. 3071-3085. Edited by A. Balows, H. G. Trüper, M. Dworkin, W. Harder \& K.-H. Schleifer. New York: Springer.

Reasoner, D. J. \& Geldreich, E. E. (1985). A new medium for the enumeration and subculture of bacteria from potable water. Appl Environ Microbiol 49, 1-7.

Reddy, G. S. N., Matsumoto, G. I., Schumann, P., Stackebrandt, E. \& Shivaji, S. (2004). Psychrophilic pseudomonads from Antarctica: Pseudomonas antarctica sp. nov., Pseudomonas meridiana sp. nov. and Pseudomonas proteolytica sp. nov. Int J Syst Evol Microbiol 54, 713719.

Saitou, N. \& Nei, M. (1987). The neighbor-joining method: a new method for reconstructing phylogenetic trees. Mol Biol Evol 4, 406425.

Sambrook, J., Frisch, E. F. \& Maniatis, T. (1989). Molecular Cloning: a Laboratory Manual, 2nd edn. Cold Spring Harbor, NY: Cold Spring Harbor Laboratory.
Sasser, M. (1990). Identification of bacteria by gas chromatography of cellular fatty acids, MIDI Technical Note 101. Newark, DE: MIDI Inc.

Sneath, P. H. A., Stevens, M. \& Sackin, M. J. (1981). Numerical taxonomy of Pseudomonas based on published records of substrate utilization. Antonie van Leeuwenhoek 47, 423-448.

Tamura, K., Dudley, J., Nei, M. \& Kumar, S. (2007). MEgA4: Molecular Evolutionary Genetics Analysis (MEGA) software version 4.0. Mol Biol Evol 24, 1596-1599.

Thompson, J. D., Gibson, T. J., Plewniak, F., Jeanmougin, F. \& Higgins, D. G. (1997). The CLUSTAL_X windows interface: flexible strategies for multiple sequence alignment aided by quality analysis tools. Nucleic Acids Res 25, 4876-4882.

Timmis, K. N. (2002). Pseudomonas putida: a cosmopolitan opportunist par excellence. Environ Microbiol 4, 779-781.

Vancanneyt, M., Witt, S., Abraham, W.-R., Kersters, K. \& Fredrickson, H. L. (1996). Fatty acid content in whole-cell hydrolysates and phospholipid fractions of pseudomonads: a taxonomic evaluation. Syst Appl Microbiol 19, 528-540.

Wu, C., Lu, X., Qin, M., Wang, Y. \& Ruan, J. (1989). Analysis of menaquinone compound in microbial cells by HPLC. Microbiology [English translation of Microbiology (Beijing)] 16, 176-178.

Yumoto, I., Kusano, T., Shingyo, T., Nodasaka, Y., Matsuyama, H. \& Okuyama, H. (2001). Assignment of Pseudomonas sp. strain E-3 to Pseudomonas psychrophila sp. nov., a new facultatively psychrophilic bacterium. Extremophiles 5, 343-349.

Zhang, D.-C., Schinner, F. \& Margesin, R. (2010). Pedobacter bauzanensis sp. nov., isolated from soil. Int J Syst Evol Microbiol 60, 2592-2595. 